OPEN ACCESS

Edited by:

Jennie Cecile Brand-Miller.

The University of Sydney, Australia

Reviewed by:

Wendy Louise Hall,

King's College London,

United Kingdom

Stephen F. Burns,

Nanyang Technological University, Singapore

Tongzhi Wu,

University of Adelaide, Australia

*Correspondence:

Daniel J. West

Daniel.west@newcastle.ac.uk

Specialty section:

This article was submitted to

Nutrition and Metabolism,

a section of the journal

Frontiers in Nutrition

Received: 27 July 2020

Accepted: 15 September 2020

Published: 20 October 2020

Citation:

Smith K, Bowden Davies KA, Stevenson EJ and West DJ (2020) The Clinical Application of Mealtime Whey Protein for the Treatment of

Postprandial Hyperglycaemia for People With Type 2 Diabetes: A Long

Whey to Go. Front. Nutr. 7:587843.

doi: 10.3389/fnut.2020.587843

\section{The Clinical Application of Mealtime Whey Protein for the Treatment of Postprandial Hyperglycaemia for People With Type 2 Diabetes: A Long Whey to Go}

\author{
Kieran Smith ${ }^{1}$, Kelly A. Bowden Davies ${ }^{1,2}$, Emma J. Stevenson ${ }^{1}$ and Daniel J. West ${ }^{1 *}$ \\ ${ }^{1}$ Population Health Sciences Institute, Newcastle University, Newcastle upon Tyne, United Kingdom, ${ }^{2}$ Department of Sport \\ and Exercise Sciences, Manchester Metropolitan University, Manchester, United Kingdom
}

Mitigating postprandial hyperglycaemic excursions may be effective in not only enhancing glycaemic control for people with type 2 diabetes but also reducing the onset of diabetes-related complications. However, there are growing concerns over the long-term efficacy of anti-hyperglycaemic pharmacotherapies, which coupled with their rising financial costs, underlines the need for further non-pharmaceutical treatments to regulate postprandial glycaemic excursions. One promising strategy that acutely improves postprandial glycaemia for people with type 2 diabetes is through the provision of mealtime whey protein, owing to the slowing of gastric emptying and increased secretion of insulin and the incretin peptides. The magnitude of this effect appears greater when whey protein is consumed before, rather than with, a meal. Herein, this dietary tool may offer a simple and inexpensive strategy in the management of postprandial hyperglycaemia for people with type 2 diabetes. However, there are insufficient long-term studies that have investigated the use of mealtime whey protein as a treatment option for individuals with type 2 diabetes. The methodological approaches applied in acute studies and outcomes reported may also not portray what is achievable long-term in practice. Therefore, studies are needed to refine the application of this mealtime strategy to maximize its clinical potential to treat hyperglycaemia and to apply these long-term to address key components of successful diabetes care. This review discusses evidence surrounding the provision of mealtime whey protein to treat postprandial hyperglycaemia in individuals with type 2 diabetes and highlights areas to help facilitate its clinical application.

Keywords: type 2 diabetes, postprandial hyperglycaemia, whey protein, second meal effect, pre-load, postprandial glycaemic control

\section{INTRODUCTION}

For people with type 2 diabetes [T2D], the regulation of postprandial glycaemia [PPG] is critical to achieving optimal glycaemic control $(1,2)$, which may mitigate complications associated with T2D and hyperglycaemia (3-7). Indeed, PPG excursions are associated with deleterious effects on the vasculature (8), and independently predict the onset of microvascular complications (9) and 
the incidence of future cardiovascular events $(10,11)$. The targeted treatment of PPG is, however, secondary, only occurring when glycaemic targets have not been met (12). Yet, meeting clinically desirable $\mathrm{HbA}_{1 \mathrm{c}}$ values does not always preclude postprandial hyperglycaemic excursions (13). Accordingly, treatment strategies should be employed to focus not only on reducing $\mathrm{HbA}_{1 \mathrm{c}}$ but controlling $\mathrm{PPG}$.

Several pharmacotherapies are effective in treating hyperglycaemia (12). However, there is uncertainty regarding their efficacy long-term (14). There are also increasing concerns with the safety and side effects of commonly prescribed agents, including thiazolidinediones, sulfonylureas and prandial insulins (15), which coupled with their rising costs (16), underscores the need for non-pharmaceutical strategies for glycaemic management.

Accumulating evidence suggests that nutrient pre-loading can profoundly improve PPG for people with T2D (1720). Consuming a macronutrient at a fixed interval before a meal primes gluco-regulatory milieu allowing for the efficient sequestration of glucose from the subsequent feed $(18,19,21)$. The efficacy of this response is, however, dependent on the nutrient composition of the pre-load (22) with a body of work supporting the use of dietary protein $(17,23)$, and in particular, whey protein [WP] as an effective strategy $(19,24)$.

In this review, we appraise recent evidence surrounding the provision of mealtime WP on PPG regulation in people with T2D and proceed to discuss experimental shortcomings surrounding this nutritional strategy and their implications for future research and clinical practice.

\section{WHEY PROTEIN AND A POSTPRANDIAL GLYCAEMIA REDUCING MILIEU}

WP is rich in branched-chain amino acids [BCAA] and bioactive peptides that augment several interconnected mechanisms associated with PPG regulation (Figure 1). Briefly, these include: amino-acid induced insulinemia $(25,26)$; augmentation of the incretin effect $(26,27)$; and suppression of dipeptidyl peptidase IV [DPP-IV] activity (28-30)-although work within humans is unclear (31). Additionally, WP delays the rate of gastric emptying $(19,32-34)$-likely mediated by glucagon-like peptide 1 [GLP-1]-related mechanisms $(35,36)$-purported as a central mechanism associated with improved PPG handling (37). The latter mechanism is of importance for individuals with controlled T2D who demonstrate accelerated gastric emptying rates (38, 39). The regulation of gastric emptying following mealtime WP may also be of significance for patients with diminished $\beta$-cell function (40), where improvements in PPG have been reported following treatments that slow gastric emptying in absence of increased insulin concentrations $(40,41)$.

Abbreviations: BCAA, branched chained amino acids; CGM, continuous glucose monitoring system; DPP-IV, dipeptidyl peptidase IV; GLP-1, glucagon-like peptide 1; PPG, postprandial glycaemia; T2D, type 2 diabetes; $\mathrm{WP}$, whey protein.

\section{MEALTIME WHEY PROTEIN AS A NON-PHARMACOLOGICAL APPROACH TO TREAT POSTPRANDIAL GLYCAEMIA}

Several lines of evidence demonstrates the capacity of WP to regulate PPG in patient $(19,31-34,42,43)$ and non-patient (44-46) populations. A summary of acute randomized-control trials utilizing mealtime WP to control PPG in individuals with $\mathrm{T} 2 \mathrm{D}$ is presented in Table 1 . Yet, the clinical impact of this inherently simple strategy remains unclear. Although Trico et al. boldly postulate that a protein-rich nutrient preload may offer similar effects to what can be achieved with available anti-hyperglycaemic agents (17), as previously proposed by Jakubowicz et al. (31), objective evidence supporting such claims is limited.

To the authors' knowledge, only one study has directly compared mealtime WP with conventional pharmacological treatments (33). In an acute intervention involving 22 metformin-treated T2D males, Wu et al. (33) reported similar reductions in PPG between the provision of a WP $(25 \mathrm{~g})$ preload, consumed $30 \mathrm{~min}$ before a test meal, and administration of the DPP-IV inhibitor, vildagliptin. Remarkably, the authors showed that combining treatments enhanced vildagliptin's efficacy by two-fold compared to its sole administration (33). Whether the reported benefits are sustained long-term, or if they have any implications in the efficacy to treat T2D, remains unknown. Clearly, the strategy of combining a dietary and pharmacological approach is an attractive avenue that warrants further investigation.

\section{CURRENT LIMITATIONS IMPEDING THE TRANSLATION OF MEALTIME WHEY PROTEIN AS A THERAPY TO TREAT TYPE 2 DIABETES}

Acute experimental trials show that mealtime WP can markedly improve PPG in people with T2D (Table 1) and may offer an adjunctive therapy for the treatment of this disease (33). However, investigations to date are largely focused on proof-ofconcept rather than efficacy to treat, adopting methodological approaches that lack real-world applicability and may not portray what could be achievable in practice. For instance, studies have primarily examined the efficacy of mealtime WP to regulate PPG after the consumption of test meals that would seldom be consumed in the T2D community [i.e., powdered potatoes with glucose $(19,32-34)$; meals rich in saturated fat $(47,48)]$ and often over a single postprandial period $(19,31-34)$. The WP doses provided have also been unrealistically large $(19,31,48)$ and presented in formats that do not align with contemporary living. While these studies prove effective in testing an experimental hypothesis, such approaches do not represent free-living eating behaviors and patterns. Therefore, it cannot be assumed that these results can be translated into everyday care or be effective in the long-term treatment of T2D. 


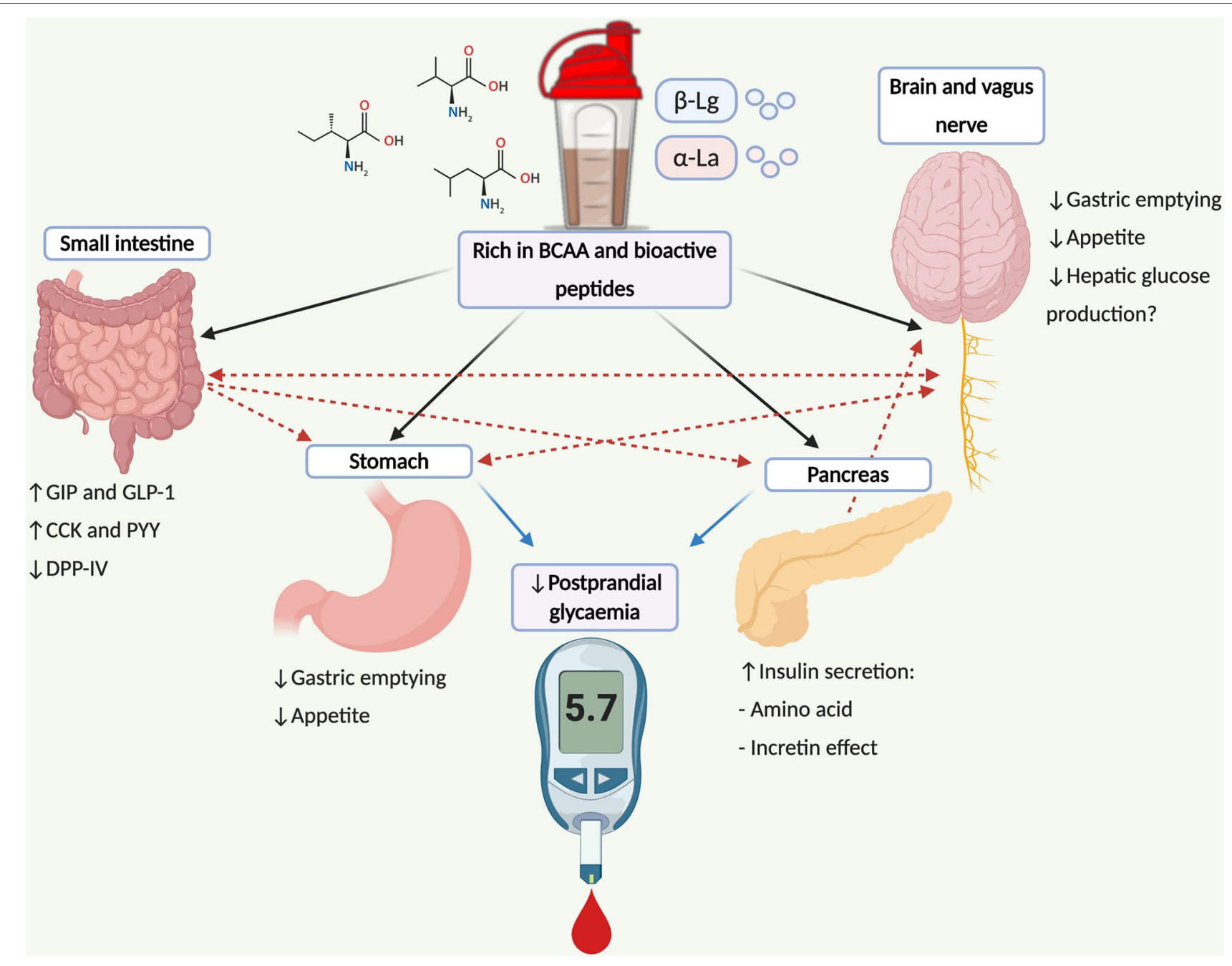

FIGURE 1 | Schematic illustration depicting mechanisms and pathways associated with postprandial glucose regulation following WP consumption and its potential application for type 2 diabetes management. WP is rich in BCAA (leucine, isoleucine and valine) and bioactive peptides ( $\alpha$-La and $\beta$-Lg) that stimulate the secretion of the incretin peptides and insulin from pancreatic $\beta$-cells. Incretin peptides, particularly GLP-1, stimulate $\beta$-cell activity, augmenting the release of insulin, where GLP-1 also regulates the rate of gastric emptying mediated through vagal afferents that convey information to the brainstem. Further gut peptides including CCK and PYY are stimulated following WP ingestion, which also delay the rate of gastric emptying and regulate the gastrointestinal transit of food via central-related mechanisms. Bioactive peptides residing WP may also inhibit DPP-IV activity, increasing the concentrations of intact incretin moieties. Insulin can also cross the blood brain barrier within the central nervous system, which may suppress appetite and regulate hepatic glucose production via the brain-liver axis. Dashed lines represent combined influences. BCAA, branch chain amino acids; CCK, cholecystokinin; DPP-IV, dipeptidyl-peptidase IV; GIP, glucose-dependent insulinotropic peptide; GLP-1,

glucagon-like peptide-1; PYY, peptide tyrosine tyrosine; $\alpha$-La, $\alpha$-lactalbumin; $\beta$-Lg, $\beta$-lactoglobulin.

\section{IMPLICATIONS FOR FUTURE RESEARCH}

\section{Supplemental Timing}

The capacity of WP to regulate PPG is dependent on supplemental timing, specifically when consumed before- rather than with- (19) or following- (46) the main meal, pertaining to an early and pronounced secretion of GLP-1 and a slowing of gastric emptying (19). Yet, a significant caveat to this approach is the timing of the pre-load and commencement of the meal. For instance, a wealth of studies have presented WP $30 \mathrm{~min}$ before the nutrient challenge $(19,31,33,34,44,45)$, which is unlikely to replicate free-living behaviors. Indeed, adherence to prandial medications, which are prescribed to align with eating occasions, can fall short due to patient forgetfulness and the burden of having to plan ahead $(49,50)$. This similarly may be the case for WP with larger pre-load "windows." Promisingly, WP consumed $\leq 15$ min before a meal augment significant glycaemic benefit (32, $42,46,51,52)$. There is additionally no further improvement in PPG when WP is consumed 30 min prior to- rather than $15 \mathrm{~min}$ before- the meal (51), which may have significance for patients adopting this strategy. However, the latter study was performed in individuals with the Metabolic Syndrome and not those with overt diabetes. It is unclear if such findings are translatable to $\mathrm{T} 2 \mathrm{D}$ individuals. 


\section{Whey Protein Dose}

Evidence to date has primarily presented unrealistically large WP doses (25-55g), entailing a significant caloric load with a large financial cost associated $(19,31,33,48)$. Indeed, the glucose-lowering efficacy of WP is reported to be dose-dependent (44). However, when accounting for the energy content of WP pre-loads (20-70 g), despite reducing energy intake at ad libitum meals compared to a control treatment, cumulative energy intake is similar $(44,53)$. This may explain why there were no differences in body mass in overweight and obese individuals with (34) and without (54) T2D following long-term (4-12wks) mealtime WP supplementation [54-75 g. $\mathrm{d}^{-1}$ (250$\left.\left.280 \mathrm{kcal} \cdot \mathrm{d}^{-1}\right)\right]$. Given the importance of weight management in the care and prevention of T2D (12), and where higher out-ofpocket costs are associated with poor adherence to anti-diabetic treatments (50), this needs careful consideration when designing long-term trials or assessing current evidence. Promisingly, small amounts of mealtime WP $(<100 \mathrm{kcal})$ have been shown to reduce PPG in people with T2D $(32-34,42)$ and are reported to not cause weight-gain following their sustained consumption (34). These data suggest that the consumption of mealtime WP $(<100 \mathrm{kcal})$ may modulate daily energy intake, which could be a secondary mechanism to improve PPG through a reduction in meal size. However, to the best of the authors' knowledge, the satiating effects of mealtime WP of any amounts has not been assessed in individuals with $\mathrm{T} 2 \mathrm{D}$.

\section{Long-Term Efficacy}

Investigations examining the efficacy of mealtime WP beyond single isolated meals are few in number $(n=2$; Table 1$)$, which is surprising given postprandial hyperglycaemic excursions display significant diurnal variances (55-57) and are highly prevalent throughout the day (13). Promisingly, we have demonstrated the capacity of mealtime WP to regulate PPG excursions beyond a single meal in adult males with T2D (42). In an acute, randomized-control trial, consuming WP (15 g) immediately prior to conventional breakfast and lunch meals reduced PPG excursions ( $\left.\sim 17 \% \mathrm{AUC}_{0-90 \mathrm{~min}}\right)$ compared to an energy-free control beverage (42). Although exploratory in nature, these findings may have importance considering glycaemic excursions following breakfast and lunch markedly contribute to the prevalence of daytime hyperglycaemia in T2D patients (13). Whether such benefits are sustained long-term and under freeliving conditions, or if they have any implications in the treatment of $\mathrm{T} 2 \mathrm{D}$, is unclear.

To the best of the authors' knowledge, only one investigation has examined the long-term efficacy of mealtime WP to treat T2D. In a randomized-control trial, Watson et al. (52) reported statistically significant, but arguably clinically insignificant, improvements in $\mathrm{HbA}_{1 \mathrm{c}}(-1.0 \mathrm{mmol} \cdot \mathrm{mol})$ following $12 \mathrm{wk}$ consumption of a pre-meal WP shake compared to a void comparator. However, this study was not designed to ascertain the relative influence of each compound of the pre-load [WP (17 g) or guar gum $(5 \mathrm{~g})$ ], which may both individually regulate glycaemia (32). The studied T2D cohort also had excellent glycaemic control at baseline $(\sim 49 \mathrm{mmol} \cdot \mathrm{mol})$ contributing to the very modest reductions in $\mathrm{HbA}_{1 \mathrm{c}}$ (58). Conversely, in a pilot study involving seven well-controlled people with T2D, serum fructosamine, which reflects recent glycaemic control, tended to be lower $(p=0.06)$ following a $28 \mathrm{~d}$ period of pre-meal WP (25 g) compared to an inert placebo (34). While the above studies suggest that mealtime WP may positively affect long-term glycaemic control $(34,52)$, this is vastly under-researched and requires validation in future trials.

Nonetheless, evidence from the latter two studies suggests that the pancreatic $\beta$-cells and gluco-regulatory mechanisms within the small intestine retain their sensitivity to prolonged WP exposure $(34,52)$. This is important considering GLP-1-mediated regulation of gastric emptying and PPG are subjected to rapid tachyphylaxis following the incretin peptide's sustained exposure $(59,60)$, where adaptive changes by which nutrients regulate gastrointestinal function have also been reported following prolonged intake of fat (61) and glucose (62).

\section{Behavioral Change or the Hawthorne Effect?}

The Hawthorne effect describes when an individual alters their behavior in response to being observed, often in a positive manner (63), making it increasingly problematic to disentangle the efficacy of an intervention to treat long-term glycaemic outcomes (64). Indeed, the effectiveness of dietary interventions when unassisted can be poor (65). Accordingly, this needs consideration when critiquing current evidence and determining mealtime WP's sustainability out with of the controlled research environment. It is therefore essential to adopt a multi-dimensional approach; assessing not only quantitative outcomes but also highlighting patient behaviors, and barriers and facilitators to this strategy. Indeed, such approaches are fundamental aspects of successful diabetes care (12).

\section{Free-Living Glycaemic Variability}

One study conducted by Watson et al. (52) suggested that mealtime WP might improve free-living PPG control as hypothesized from the observed reductions in $\mathrm{HbA}_{1 \mathrm{c}}$. However, meeting clinically desirable $\mathrm{HbA}_{1 \mathrm{c}}$ values does not guarantee negligible postprandial hyperglycaemic excursions (13). Indeed, reliance on $\mathrm{HbA}_{1 \mathrm{c}}$ to characterize alterations in glycaemic control fails to account for daily glycaemic excursions and variances (66).

In an era of personalized and precision medicine, advancements in continuous glucose monitoring systems [CGM] can overcome limitations associated with surrogate measures of glycaemia (67). CGM allows for the detailed assessment of intra- and inter-daily glycaemic excursions under free-living conditions $(66,67)$. Yet, there is limited information regarding $24 \mathrm{~h}$ glycaemic exposure following concerted dietary interventions.

One small study has used CGM to assess free-living glycaemic control following mealtime WP $(21 \mathrm{~g})$ in people with T2D over a $48 \mathrm{~h}$ free-living period, reporting no benefit of WP compared to an inert placebo (68). However, such findings were largely compounded by the heterogenic cohort studied, as acknowledged by the authors, and may have been affected by various extraneous variables that were not accounted for. The $48 \mathrm{~h}$ period assessed is substantially less than what is 
TABLE 1 | A summary of acute, randomized-control, crossover trials that have utilized mealtime WP to regulate postprandial glycaemic excursions in people with T2D.

\begin{tabular}{|c|c|c|c|c|c|c|}
\hline References & Studied cohort & Design & Treatment & Comparator & Findings & Key messages \\
\hline $\begin{array}{l}\text { Bjørnshave } \\
\text { et al. (47) }\end{array}$ & $\begin{array}{l}\text { Metformin-controlled } \\
\text { T2D }(n=12 ; 3 F / 9 M)- \\
\text { Age: } 62.9 y[57-68.8] \text { - } \\
\mathrm{HbA}_{1 \mathrm{c}}: 50 \mathrm{mmol} \cdot \mathrm{mol} \\
\text { [range: } 46-52] \\
\text { - Dx: Not reported. } \\
\text { Age-weight matched } \\
\text { controls }(n=12)\end{array}$ & $\begin{array}{l}\text { - Randomized, crossover design. } \\
\text { - Two visits separated by } 7 \mathrm{~d} \text {. } \\
\text { - Treatments were consumed } \\
\text { before }(15 \mathrm{~min}) \text { or with a high-fat } \\
\text { breakfast meal }(932 \mathrm{kcal}: 40 \mathrm{~g} \\
\mathrm{CHO})+1,500 \mathrm{mg} \\
\text { acetaminophen. } \\
\text { - Fasting and postprandial }(6 \mathrm{~h}) \\
\text { blood samples and VAS taken. }\end{array}$ & $\begin{array}{l}- \text { WPI } \\
(17.6 \mathrm{~g}) \\
\text { pre-load. }\end{array}$ & $\begin{array}{l}\text { - WPI (17.6 g) } \\
\text { co-ingested. }\end{array}$ & $\begin{array}{l}\text { - In individuals with T2D, glycaemia } \\
\text { was greater throughout compared to } \\
\text { healthy controls. } \\
\text { - WP pre-load } \uparrow \text { early insulin ( } \sim 8 \% \\
\text { AUC } 0 \text {-30min) and GIP secretion } \\
\left(\sim 15 \% \text { AUC } C_{0-30 m i n)} \text { ) without affecting }\right. \\
\text { PPG in both cohorts. } \\
\text { - Rates of gastric emptying (i.e., } \\
\text { acetaminophen pharmacokinetics) } \\
\text { were } \leftrightarrow \text { between groups. } \\
\text { - Gastric emptying was slower } \\
\text { following the WP pre-load ( } t= \\
0-30 \text { min). } \\
\text { - WP timing did not affect } \\
\text { postprandial lipemic markers in } \\
\text { both groups. }\end{array}$ & $\begin{array}{l}\text { PPG is similar when WP is } \\
\text { consumed } 15 \text { min before or with a } \\
\text { fat-rich meal, despite a delay in } \\
\text { gastric emptying and an early } \\
\text { increase in insulin following the WP } \\
\text { pre-load. }\end{array}$ \\
\hline $\begin{array}{l}\text { Frid et al. } \\
\text { (24) }\end{array}$ & $\begin{array}{l}\text { Diet-controlled T2D }(n \\
=14 ; 6 \mathrm{~F} / 8 \mathrm{M}) \\
\text { - Age: } 27-69 \mathrm{y} \\
\text { - BMl: } 26.2 \pm \\
3.1 \mathrm{~kg} \cdot \mathrm{m}^{2} \\
-\mathrm{HbA}: 36 \pm \\
3 \mathrm{mmol} \cdot \mathrm{mol} \\
\text { - Dx: Not reported. }\end{array}$ & $\begin{array}{l}\text { - Randomized, crossover design. } \\
\text { - Two visits separated by } 7 \mathrm{~d} \text {. } \\
\text { - High Gl breakfast and lunch } \\
\text { (served } 4 \mathrm{~h} \text { post breakfast) } \\
\text { served with addition either } \\
\text { treatment or comparator. } \\
\text { - Fasting and postprandial blood } \\
\text { samples taken ( } 4 \mathrm{~h} \text { ). }\end{array}$ & $\begin{array}{l}-\mathrm{WP} \\
(18.2 \mathrm{~g})\end{array}$ & $\begin{array}{l}\text { - Ham and } \\
\text { lactose } \\
\text { (matched for } \\
\text { protein and } \\
\mathrm{CHO} \text {. }\end{array}$ & $\begin{array}{l}\text { - PPG } \leftrightarrow \text { between treatments at } \\
\text { breakfast but was } \downarrow \text { by } 21 \% \text { following } \\
\text { lunch with whey ingestion. } \\
\text { - WP } \uparrow \text { insulin secretion by } 53 \% \text { and } \\
49 \% \text { (AUC } 0-180 \text { min) following } \\
\text { breakfast and lunch, respectively. } \\
- \text { WP } \uparrow \text { GIP following both meals } \\
\text { (20-34\% AUC } 0-180 \text { min) with no effect } \\
\text { on GLP-1. }\end{array}$ & $\begin{array}{l}\text { The ingestion of WP at lunch } \\
\text { reduces PPG, associated with an } \\
\text { increase insulin and GIP } \\
\text { concentrations. }\end{array}$ \\
\hline $\begin{array}{l}\text { King } \\
\text { et al. (42) }\end{array}$ & $\begin{array}{l}\text { Metformin } \pm \text { diet } \\
\text { controlled T2D }(n= \\
11 \mathrm{M}) \\
\text { - Age: } 54.9 \pm 2.3 \mathrm{y} \\
\text { - BMl: } 31.8 \pm \\
2.6 \mathrm{~kg} \cdot \mathrm{m}^{2} \\
-\mathrm{HbA} 1 \mathrm{c}: 51.3 \pm \\
3.4 \mathrm{mmol} \cdot \mathrm{mol} \\
\text { - Dx: } 4 \pm 1 \mathrm{y}\end{array}$ & $\begin{array}{l}\text { - Randomized, single blind, } \\
\text { crossover design. } \\
\text { - Three visits separated by } 7 \mathrm{~d} \text {. } \\
\text { - Treatments were consumed } \\
\text { immediately before } \\
\text { mixed-nutrient breakfast ( } 387 \\
\text { kcal: } 56 \mathrm{~g} \mathrm{CHO} \text { ) and lunch meals } \\
\text { ( } 879 \mathrm{kcal}: 117 \mathrm{~g} \mathrm{CHO}) \text {. } \\
\text { - Fasting and postprandial ( } 3 \mathrm{~h} \text { ) } \\
\text { blood samples, and VAS taken. } \\
\text { - Glycaemia monitored by CGM. }\end{array}$ & $\begin{array}{l}- \text { WPC } \\
(15 \mathrm{~g})\end{array}$ & $\begin{array}{l}\text { - WPH }(15 \mathrm{~g}) \\
\text { - Null CON } \\
\text { (water). }\end{array}$ & $\begin{array}{l}\text { - WPC } \downarrow \text { peak }(\sim 1.5 \text { mmol.L) and } \\
\text { PPG }(\sim 17 \% \text { AUC } 0-90 \mathrm{~min}) \text { vs. CON. } \\
\text { Glycaemia } \leftrightarrow \text { between WPC } \\
\text { and WPC. } \\
\text { - Total insulin secretion was } \uparrow \\
\left.\text { ( 14-20\% AUC } C_{0-180 m i n}\right) \text { following } \\
\text { breakfast with WP treatments. } \\
\text { - No supplemental effect on } \\
\text { incretin peptides. } \\
\text { - WP } \uparrow \text { subjective feelings of satiety. }\end{array}$ & $\begin{array}{l}\text { Consuming WP immediately } \\
\text { before conventional breakfast and } \\
\text { lunch meals reduces peak PPG } \\
\text { and PPG excursions. }\end{array}$ \\
\hline $\begin{array}{l}\text { Jakubowicz } \\
\text { et al. (31) }\end{array}$ & $\begin{array}{l}\text { Metformin } \pm \text { SU } \\
\text { treated T2D }(n= \\
15 ; 6 F / 9 M) \\
\text { - Age: } 64.1 \pm 1.4 y \\
\text { - BMl: } 26.7 \pm \\
1.2 \mathrm{~kg} \cdot \mathrm{m}^{2} \\
-\mathrm{HbA_{10 } :} 50 \pm \\
2 \mathrm{mmol} \cdot \mathrm{mol} \\
\text { Dx: } 8.0 \pm 1.6 \mathrm{y}\end{array}$ & $\begin{array}{l}\text { - Randomized, crossover design. } \\
\text { - Two visits separated by } 14 \mathrm{~d} \text {. } \\
\text { - Treatments consumed } 30 \mathrm{~min} \\
\text { prior to a high-Gl breakfast. } \\
\text { Fasting and postprandial ( } 3 \mathrm{~h} \text { ) } \\
\text { blood samples taken. }\end{array}$ & $\begin{array}{l}- \text { WPC } \\
(50 \mathrm{~g})\end{array}$ & $\begin{array}{l}\text { - Null CON } \\
\text { (water). }\end{array}$ & $\begin{array}{l}- \text { WP } \downarrow \text { peak PPG }(\sim 6 \text { mmol.L) and } \\
\text { total PPG }\left(-28 \% \text { AUC } C_{0-180 m i n}\right) \text {. } \\
- \text { WP } \uparrow \text { total insulin }(+108 \% \\
\text { AUC } 0-180 \mathrm{~min}), \text { C-peptide }(+43 \% \\
\text { AUC } 0-180 \mathrm{~min}) \text { and GLP-1 (+141\% } \\
\text { AUC } 0-180 \mathrm{~min}) \text { exposure. } \\
- \text { WP } \uparrow \text { intact/total GLP-1 ratio vs. } \\
\text { CON }(\sim 65 \%) \text { with } \leftrightarrow \text { on } \\
\text { plasma DPP-IV. }\end{array}$ & $\begin{array}{l}\text { Consuming a WP pre-load } 30 \text { min } \\
\text { before a high-Gl breakfast reduces } \\
\text { peak PPG and PPG excursions, } \\
\text { associated with increased } \\
\text { secretion of insulin and GLP-1. }\end{array}$ \\
\hline
\end{tabular}




Comparator
WP $(55 \mathrm{~g})$ in
meal
Pre-load
only (CON)

\begin{tabular}{|c|c|c|c|}
\hline References & Studied cohort & Design & Treatment \\
\hline $\begin{array}{l}\text { Ma et al. } \\
\text { (19) }\end{array}$ & $\begin{array}{l}\text { Diet-controlled T2D }(n \\
=8 ; 1 \mathrm{~F} / 7 \mathrm{M}) \\
\text { - Age: } 58 \pm 3 \mathrm{y} \\
\text { - BMl: } 28.6 \pm \\
1.3 \mathrm{~kg} \cdot \mathrm{m}^{2} \\
\text { - HbA } \mathrm{Hc}: 42 \pm \\
2 \mathrm{mmol} \cdot \mathrm{mol} \\
\text { - Dx: } 5.4 \pm 1.1 \mathrm{y} .\end{array}$ & $\begin{array}{l}\text { - Randomized, crossover design. } \\
\text { - Three visits. } \\
\text { - A soup pre-load consumed } \\
30 \text { min prior to a high-Gl } \\
\text { semi-solid meal ( } 302 \mathrm{kcal}: 59 \mathrm{~g} \\
\mathrm{CHO} \text {. WP was either added to } \\
\text { the pre-load, the meal or } \\
\text { omitted. } \\
\text { - Gastric emptying measured by } \\
\text { scintigraphy. } \\
\text { - Fasting and postprandial (6 h) } \\
\text { blood samples taken. }\end{array}$ & $\begin{array}{l}- \text { WP } \\
(55 \mathrm{~g}) \text { in } \\
\text { pre-load }\end{array}$ \\
\hline
\end{tabular}

-WP $\downarrow$ peak glycaemia $\sim 3 \mathrm{mmol} \cdot \mathrm{L}$ consumed with the meal $(-45 \%)$; $\leftrightarrow$

- Randomized, single-blind,

(34) $=7 ; 4 \mathrm{~F} / 3 \mathrm{M}$ )

- Age: $60 \pm 2 y$ BMl: $31 \pm 2 \mathrm{~kg} \cdot \mathrm{m}^{2}$ $-\mathrm{HbA}_{10}: 42 \pm$ $2 \mathrm{mmol} \cdot \mathrm{mo}$ - Dx: not reported.

$\begin{array}{ll}\text { Mortensen } & \text { Metformin } \pm \text { SU } \\ \text { et al. (48) } & \text { treated T2D }(n= \\ & 12 ; 6 \mathrm{~F} / 6 \mathrm{M}) \\ & - \text { Age: } 64.6 \pm 3.3 \mathrm{y} \\ & -\mathrm{BMl}: 28.9 \pm \\ & 3.7 \mathrm{~kg} \cdot \mathrm{m}^{2} \\ & -\mathrm{HbA_{10 }}: 51 \pm \\ & 1 \mathrm{mmol} \cdot \mathrm{mol} \\ & -\mathrm{Dx} \text { : not reported. } \\ & \text { Metformin } \pm \\ \text { Watson } & \text { diet-controlled T2D ( } n \\ \text { et al. (32) } & =21 ; 5 \mathrm{~F} / 16 \mathrm{M}) \\ & - \text { Age: } 66 \pm 2 \mathrm{y} \\ & -\mathrm{BMl}: 30.8 \pm 1 \mathrm{~kg} \cdot \mathrm{m}^{2} \\ & -\mathrm{HbA} 1 \mathrm{c}: 46.4 \pm \\ & 1.5 \mathrm{mmol} \cdot \mathrm{mol} \\ & -\mathrm{Dx}: 6.3 \pm 1.9 \mathrm{y} .\end{array}$

\section{crossover design.}

Days 1 and 28, treatments

were consumed $30 \mathrm{~min}$ prior to high-Gl breakfast (314 kcal: $62 \mathrm{~g}$ $\mathrm{CHO}$ ).

- Gastric emptying measured by scintigraphy

- Fasting and postprandial (6h) blood samples taken.

Free-living phase

- Treatments consumed $30 \mathrm{~min}$ prior to each main meal for $28 d$ before $14 d$ washout.

Randomized, crossover design - Four visits separated by 2-5wks.

Four different protein sources consumed with a high-fat test meal ( 1,150 kcal: $45 \mathrm{~g} \mathrm{CHO}$. - Fasting and postprandial (8h) blood samples taken.

\section{Randomized, single-blind}

crossover design.

- Four visits separated by $4 \mathrm{~d}$.

- Treatments (mixed with $150 \mathrm{ml}$

water) consumed $15 \mathrm{~min}$ before

semi-solid high-Gl breakfast (369 kcal: $61 \mathrm{~g} \mathrm{CHO)}$.

Gastric emptying measured by ${ }^{3} \mathrm{C}$ GEBT.

- Fasting and postprandial (4h)

blood samples taken. 1-2mmol.L following WP and WP - PPG (iAUC 15 -240min) were 15\% vs. CON with $\leftrightarrow$ between WP trials. - PPG (iAUC $0-300 \mathrm{~min}) \downarrow$ following the WP pre-load $(-51 \%)$ and when between WP trials.

-WP pre-load $\downarrow$ early (0-45 min) PPG compared to WP in the meal.

- Insulin, GLP-1, GIP and CCK responses with the WP pre-load.

- Both WP trials delayed gastric emptying T50, which was the slowest with the WP pre-load ( 35\%).

\section{$(25$}

Consuming WP 30 min before or with a high-Gl breakfast reduces peak PPG and PPG excursions.

WP is effective in stimulating insulin and incretin peptide secretion and delaying gastric emptying.

A WP pre-load is more effective in reducing early PPG excursions compared to its consumption with a meal owing to an early increase in GLP-1 and slowing of gastric emptying

Consuming WP $30 \mathrm{~min}$ before a high-Gl breakfast delays gastric emptying and reduces peak PPG. The ability of WP to regulate PPG and gastric emptying is sustained after its long-term consumption.

\section{WP vs. CON.}

- Gastric emptying was delayed after

No change in PPG or gastric emptying rates following $28 \mathrm{~d}$ of supplement consumption.

Serum fructasomine tended to be lower following WP $(p=0.06)$ vs. CON.

$-\mathrm{HbA}_{1 c}$ unaffected by WP

- Energy intake and body mass similar throughout both 28d periods.

$\begin{array}{ll}- \text { WP } & - \text { Casein } \\ (45 \mathrm{~g}) & (45 \mathrm{~g}) \\ & - \text { Cod }(45 \mathrm{~g}) \\ & - \text { Gluten }(45 \mathrm{~g})\end{array}$

$-W P \downarrow P P G$ (iAUC $0-480 \mathrm{~min}$ ) by $\sim 30-50 \%$ vs. to other treatments. Insulin and incretin peptide responses were all similar between treatments. -WP $\downarrow$ postprandial Tg and free fatty acids ( iAUC $_{0-360 \mathrm{~min}}$ ) by $\sim 25 \%$ vs. other treatments.

Early glycaemia (0-90 min) $\downarrow$ by guar gum vs. other treatments; $\leftrightarrow$ between WP and WP + guar gum. lower following WP and WP + guar gum vs. other treatments; $\leftrightarrow$

between WP and WP + guar gum - WP $\uparrow$ insulin ( 32\%) and GLP-1 ( 86\%) iAUC-15-240min Vs. CON. - Both WP treatments delayed gastric emptying T50 vs. CON ( 9-17\%).
$(5 \mathrm{~g})$ (5 g)

- Null CON $60 \mathrm{mg})$
Consumption of WP with a fat-rich meal reduces PPG excursions compared to casein, cod and increased insulin and incretin peptide concentrations.

A WP pre-load, consumed $15 \mathrm{~min}$ before a high-Gl meal, reduces PPG excursions compared to guar gum or a CON drink.

WP is associated with an increase in insulin and GLP-1 and slowing of gastric emptying.

Combining guar gum with WP did not further reduce PPG compared to WP. gluten proteins, independent of 


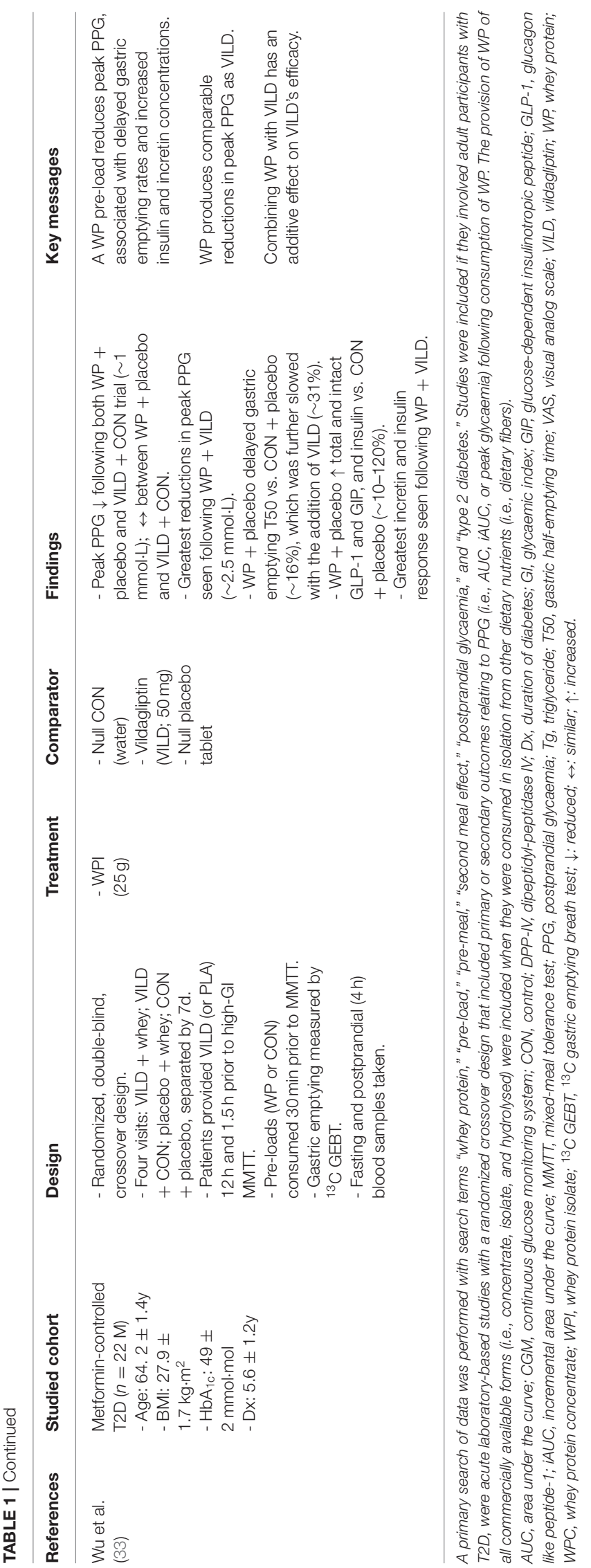

recommended when assessing free-living glycaemia with CGM (67) -albeit such recommendations are primary care specific. Nonetheless, duration of assessment needs consideration for future investigations, particularly when free-living behaviors are known to change when under observation (63).

\section{Homogenous Study Populations}

Previous interventions have studied the application of mealtime WP in people with well-controlled $\mathrm{T} 2 \mathrm{D}\left(\mathrm{HbA}_{1 \mathrm{c}}<53 \mathrm{mmol} \cdot \mathrm{mol}\right)$ treated with first-line therapies, excluding individuals with less stringent glycaemic control and treated with intensified regimens. Indeed, individuals likely to see the greatest benefit of mealtime WP are those with moderately-controlled diabetes $\left(\mathrm{HbA}_{1 \mathrm{c}}<70 \mathrm{mmol} \cdot \mathrm{mol}\right)$ where PPG is the predominant contributor to overall glycaemic control (1). Yet, considering that at a population level only $\sim 50 \%$ of people with T2D meet the $\mathrm{HbA}_{1 \mathrm{c}}$ target of $\leq 53 \mathrm{mmol} \cdot \mathrm{mol}$ (69), and within $6 \mathrm{y}$ of starting oral hyperglycaemic agents, $\sim 25 \%$ require exogenous insulin (70), evidence is based on cohorts that are not representative of the wider patient population.

The regulation of PPG also occurs, in part, by insulinindependent mechanisms (37, 40, 71-73). Thus, for individuals with more advanced diabetes, the use of strategies that modulate PPG by pancreatic and extra-pancreatic means is appealing (40). It is conceivable that the pleiotropic constituents and stimulated pathways following mealtime WP (Figure 1) may offer clinical benefit to individuals with limited $\beta$-cell function or advanced T2D, who presently have been ignored when studying WP's glucose-lowering efficacy.

\section{Combination Therapy}

T2D is largely defined with relative rather than absolute insulin deficiency (74). Therefore, strategies that enhance $\beta$-cell activity may be of therapeutic benefit for those with advanced diabetes. Indeed, GLP-1 receptor agonists work, in part, by enhancing $\beta$ cell activity (75). Given the incretin and insulinotropic properties of WP purported to regulate PPG (Figure 1), combining WP with basal therapies may present an effective long-term strategy to enhance glycaemic control. This concept has proven effective with the combination of basal insulin and incretin agonists compared to basal insulin regimens alone in poorly-controlled T2D patients $(76,77)$. With this in mind and where WP enhances vildagliptin's efficacy (33), combining mealtime WP with antidiabetic agents may present a novel strategy to achieve glycaemic control coupled with the low propensity of adverse side effects such as weight gain and hypoglycaemia.

\section{The Presentation of Whey Protein and Its Associated Implications for Free-Living Adherence}

Adherence to anti-hyperglycaemic treatments is not a single behavior but a dynamic constellation of behaviors influenced by social, environmental and individual circumstances (69). Thus, understanding the various psychosocial elements associated with a given treatment is critical to maximizing its application and clinical utility (12). To the best of the authors' knowledge, these 
are factors that have not been considered with the application of mealtime WP.

Studies have presented WP as dry powders that require dilution with water, producing solutions that are often inconvenient and large in volume $(\sim 350 \mathrm{ml})(19,31)$ and largely unpalatable, requiring further flavoring $(19,31,33)$ and "mouth rinsing" to eliminate any aftertaste $(46,78)$. Although effective under controlled conditions, this unlikely represents a convenient approach outside of the laboratory. Indeed, there is a general unwillingness to consume powdered protein supplements publicly (79) with taste and convenience largely determining eating behaviors (80). Even where available evidence suggests the use of a particular treatment, patient preference determines their application (12). Thus, to ensure free-living applicability and long-term sustainability, the pre-loads provided need to be extrapolated into treatments that are compatible with contemporary lifestyles. Given the preponderance and social acceptance of "grab and go" foods, providing a palatable and discrete WP beverage, similar to a yogurt drink for example, may be an effective strategy to increase adherence and exert clinical benefit within the community setting.

\section{Potential Adverse Effects}

When considering the therapeutic use of mealtime WP, it is also pertinent to recognize potential adverse events that may occur. Indeed, concerns have been raised as a consequence of elevated nutrient signaling that may accelerate pancreatic islet fatigue and failure. Primarily, these are observations from incidence rates of diabetes in pre-diabetic mice models fed a high-protein diet $(81,82)$. However, there are also reductions in the efficacy of oral insulin secretagogue therapies over time-in part due to a decline in the $\beta$-cells' insulin-secretory capacity (83)-where their use are also reported predictors of exogenous insulin initiation (84).

Long-term exposure of hyperinsulinemia is reported to compromise whole-body insulin sensitivity (85) and increase the atherosclerotic milieu (86). Therefore, the chronic application of WP and its associated insulinotropic effects may counterintuitively desensitize insulin's action and be associated with adverse cardio-metabolic outcomes. However, the long-term administration of sulfonylureas', which increase both basal and postprandial insulinaemia, are not associated with an increase in cardiovascular events (6). Furthermore, the periodic elevations in postprandial insulinemia that follow WP ingestion $(\sim 20 \mathrm{~g})$ persist for $\sim 120 \mathrm{~min}(32,33,87)$, where sustained WP supplementation is associated with a reduction, rather than an increase, in metabolic risk factors in insulinresistant individuals $(54,88,89)$. These data suggest that the insulinotropic properties of WP would pose little consequence to long-term metabolic health. Yet, mealtime WP's influence on the regulation of hepatic lipid metabolism, which is sensitive to hyperinsulinemia and is upregulated in insulin-resistant states (90), is not known. Considering the reciprocal relationship between hyperinsulinemia and steatosis (91), dyslipidaemia (92), and cardiovascular events (93), this is an avenue that needs further consideration.

Ambient elevations in fasting plasma BCAA are a metabolic signature of dysglycaemic populations (94-96), and prospectively predict T2D $(97,98)$, suggesting that dietary protein/BCAA intake could be an important regulator of glucose tolerance. Indeed, BCAA surfeit through infusion/pulse feeding protocols impairs insulin signaling and glucose disposal in humans (99101). However, the observed elevations in plasma BCAA within insulin-resistant individuals may be attributed to dysregulated BCAA catabolism (102) rather than dietary BCAA intake per se $(103,104)$. Moreover, and in contrast to BCAA infusion/pulse feeding protocols, the surge in plasma BCAA following protein consumption are not sustained, returning to their nadir within $\sim 180$ min $(42,105)$. In fact, the acute influx of amino acids following dietary protein pre-loads are associated with increased $\beta$-cell sensitivity to glucose (106) and improved PPG handling (105), as has been demonstrated acutely across various insulinresistant populations $(19,31-33,42,46,107)$. It, therefore, appears unlikely that the BCAA content of a small WP pre-load would be sufficient to exacerbate defects in insulin sensitivity as observed under BCAA surfeit (99-101).

Dietary proteins, in addition to stimulating insulin secretion, also stimulate the release of glucagon from pancreatic alphacells (108), which initiates hepatic glucose output. Indeed, several studies demonstrate that mealtime WP supplementation increases postprandial glucagonemia in insulin-resistant individuals with $(32,33)$ and without $(51,87,109)$ overt T2D. However, despite increasing glucagon concentrations, PPG is consistently improved following the ingestion of WP $(32,33,51,87,109)$. This is likely due to the concomitant increase in insulin concentrations, which is particularly effective in suppressing glycogenolysis (108). The consumption of WP also increases GLP-1 $(19,31-33)$, which may suppress hepatic glucose output (110) and enhance peripheral glucose uptake (72), independent of changes in islet hormones. Nonetheless, the relevance of increasing glucagon concentrations following consumption of mealtime WP in relation to PPG remains controversial. Future studies should include approaches designed to assess mealtime WP's influence on the relative contribution of glucose from both exogenous and endogenous origins to the total glucose pool. This would also provide a greater understanding of the mechanisms underpinning WP's gluco-regulatory effects.

\section{FUTURE RESEARCH CONSIDERATIONS}

\section{Clinically Important Outcomes}

Acute studies demonstrate immediate glycaemic benefit from mealtime WP, providing valuable information on the immediate post-meal responses. However, whether such outcomes translate to clinically meaningful benefits are unclear. Indeed, changes in metabolic health require chronic improvements in PPG and other cardio-metabolic markers, outcomes that cannot be achieved within the acute setting.

One study has investigated the role of pre-meal WP to treat T2D, as quantified by $\mathrm{HbA}_{1 c}$ (52). While $\mathrm{HbA}_{1 c}$ is used as a primary outcome to assess glycaemic control and is a surrogate marker assessing the risk of diabetes complications (4), it fails to tell researchers or clinicians other meaningful outcomes outside of the weighted-average glycaemia over the preceding $\sim 12 \mathrm{wks}$ (66). Nonetheless, the importance of reporting $\mathrm{HbA}_{1 c}$ for the appraisal of diabetic treatments should not be undervalued; 
rather, it should be complimented by other glycaemic measures (67). Studies are needed to include and specify further clinically meaningful glycaemic outcomes that not only include $\mathrm{HbA}_{1 \mathrm{c}}$ but also time in euglycaemic range, frequency and severity of hypoglycaemic and hyperglycaemic events, glycaemic variability, and patient-reported outcomes.

\section{Understanding the Clinical Potential in the Wider Diabetes Population}

Investigations have studied the efficacy of mealtime WP in patients that do not represent the wider T2D population, excluding those with more advanced diabetes and treated with insulin regimens. Yet, insulin-dependent T2D individuals retain varying degrees of clinically functioning $\beta$-cells (74) and might be responsive to nutrient-mediated $\beta$-cell stimulation. The complex and pleiotropic actions of mealtime WP (Figure 1) may also present therapeutic benefit to individuals with limited $\beta$-cell function (40). Studies are encouraged to investigate this therapy within realistic $\mathrm{T} 2 \mathrm{D}$ populations and to adopt approaches to disentangle its mechanisms to treat hyperglycaemia.

\section{Design of Studies}

To examine the real-world sustainability of mealtime WP, studies are encouraged to provide WP beverages that are in formats and at times that complement modern living patterns. It is also essential for future investigations to work with the patient, highlighting potential barriers and facilitators to the application of this mealtime strategy.

\section{REFERENCES}

1. Monnier L, Lapinski H, Colette C. Contributions of fasting and postprandial plasma glucose increments to the overall diurnal hyperglycemia of type 2 diabetic patients: variations with increasing levels of HbA1c. Diabetes Care. (2003) 26:881-5. doi: 10.2337/diacare.26.3.881

2. Woerle HJ, Neumann C, Zschau S, Tenner S, Irsigler A, Schirra J, et al. Impact of fasting and postprandial glycemia on overall glycemic control in type 2 diabetes: importance of postprandial glycemia to achieve target HbAlc levels. Diabetes Res Clin Pract. (2007) 77:2805. doi: 10.1016/j.diabres.2006.11.011

3. Holman RR, Paul PK, Bethel MA, Matthews DR, Neil AW. 10-Year followup of intensive glucose control in type 2 diabetes. N Engl J Med. (2008) 359:1577-89. doi: 10.1056/NEJMoa0806470

4. Stratton IM, Adler AI, Neil HA, Matthews DR, Manley SE, Cull CA, et al. Association of glycaemia with macrovascular and microvascular complications of type 2 diabetes (UKPDS 35): prospective observational study. BMJ. (2000) 321:405-12. doi: 10.1136/bmj.321.7258.405

5. Gaede P, Lund-Andersen $\mathrm{H}$, Parving $\mathrm{HH}$, Pedersen O. Effect of a multifactorial intervention on mortality in type 2 diabetes. $N$ Engl J Med. (2008) 358:580-91. doi: 10.1056/NEJMoa0706245

6. UK Prospective Diabetes Study (UKPDS) Group. Intensive blood-glucose control with sulphonylureas or insulin compared with conventional treatment and risk of complications in patients with type 2 diabetes (UKPDS 33). UK prospective diabetes study (UKPDS) group. Lancet. (1998) 352:83753. doi: 10.1016/S0140-6736(98)07019-6

7. Esposito K, Ciotola M, Carleo D, Schisano B, Sardelli L, Di Tommaso D, et al. Post-meal glucose peaks at home associate with carotid intima-media thickness in type 2 diabetes. J Clin Endocrinol Metab. (2008) 93:134550. doi: $10.1210 /$ jc. $2007-2000$

\section{Supplemental Dose}

It is important to consider the additional energy associated with mealtime WP when evaluating its long-term application. Although work demonstrates that the consumption of $15-20 \mathrm{~g}$ $(\sim 100 \mathrm{kcal})$ of WP improves PPG in T2D individuals $(32,42)$, this may translate to an increase in long-term gross energy intake. The minimum efficacious dose of mealtime WP needs to be established.

\section{CONCLUSION}

For people with controlled T2D, experimental evidence demonstrates that the application of pre-meal WP results in acute improvements in PPG, which if sustained long-term, may have therapeutic significance. Yet, the clinical application of mealtime WP remains to be established with literature to date idling on proof of concept rather than efficacy to treat T2D. Addressing the experimental limitations highlighted in this report are critical to understanding the mechanisms underpinning WP's potential clinical benefit and assessing its acceptance within the wider scientific community. Only then can mealtime WP be considered a therapeutic option for people with T2D.

\section{AUTHOR CONTRIBUTIONS}

$\mathrm{KS}, \mathrm{KB}, \mathrm{ES}$, and DW wrote and reviewed the manuscript. All authors approved the final manuscript.
8. Ceriello A, Esposito K, Piconi L, Ihnat MA, Thorpe JE, Testa R, et al. Oscillating glucose is more deleterious to endothelial function and oxidative stress than mean glucose in normal and type 2 diabetic patients. Diabetes. (2008) 57:1349-54. doi: 10.2337/db08-0063

9. Shiraiwa T, Kaneto H, Miyatsuka T, Kato K, Yamamoto K, Kawashima A, et al. Postprandial hyperglycemia is a better predictor of the progression of diabetic retinopathy than HbAlc in Japanese type 2 diabetic patients. Diabetes Care. (2005) 28:2806-7. doi: 10.2337/diacare.28.11.2806

10. Cavalot F, Pagliarino A, Valle M, Di Martino L, Bonomo K, Massucco $\mathrm{P}$, et al. Postprandial blood glucose predicts cardiovascular events and all-cause mortality in type 2 diabetes in a 14-year follow-up: lessons from the san luigi gonzaga diabetes study. Diabetes Care. (2011) 34:223743. doi: $10.2337 / \mathrm{dc} 10-2414$

11. Meigs JB, Nathan DM, D'Agostino RB, Wilson PW. Fasting and postchallenge glycemia and cardiovascular disease risk: the framingham offspring study. Diabetes Care. (2002) 25:184550. doi: $10.2337 /$ diacare.25.10.1845

12. Davies MJ, D’Alessio DA, Fradkin J, Kernan WN, Mathieu C, Mingrone G, et al. Management of hyperglycaemia in type 2 diabetes, 2018. A consensus report by the American diabetes association (ADA) and the European association for the study of diabetes (EASD). Diabetologia. (2018) 61:246198. doi: 10.1007/s00125-018-4729-5

13. van Dijk J-W, Manders RJ, Hartgens F, Stehouwer CD, Praet SF, van Loon LJ. Postprandial hyperglycemia is highly prevalent throughout the day in type 2 diabetes patients. Diabetes Res Clin Pract. (2011) 93:317. doi: 10.1016/j.diabres.2011.03.021

14. Tahrani AA, Bailey CJ, Del Prato S, Barnett AH. Management of type 2 diabetes: new and future developments in treatment. Lancet. (2011) 378:182-97. doi: 10.1016/S0140-6736(11)6 0207-9 
15. Tahrani AA, Barnett AH, Bailey CJ. Pharmacology and therapeutic implications of current drugs for type 2 diabetes mellitus. Nat Rev Endocrinol. (2016) 12:566-92. doi: 10.1038/nrendo.2016.86

16. Riddle MC, Herman WH. The cost of diabetes care-an elephant in the room. Diabetes Care. (2018) 41:929-32. doi: 10.2337/dci18-0012

17. Trico D, Baldi S, Tulipani A, Frascerra S, Macedo MP, Mari A, et al. Mechanisms through which a small protein and lipid preload improves glucose tolerance. Diabetologia. (2015) 58:2503-12. doi: 10.1007/s00125-015-3710-9

18. Gentilcore D, Chaikomin R, Jones KL, Russo A, Feinle-Bisset C, Wishart $\mathrm{JM}$, et al. Effects of fat on gastric emptying of and the glycemic, insulin, and incretin responses to a carbohydrate meal in type 2 diabetes. J Clin Endocrinol Metab. (2006) 91:2062-7. doi: 10.1210/jc.2005-2644

19. Ma J, Stevens JE, Cukier K, Maddox AF, Wishart JM, Jones KL, et al. Effects of a protein preload on gastric emptying, glycemia, and gut hormones after a carbohydrate meal in diet-controlled type 2 diabetes. Diabetes Care. (2009) 32:1600-2. doi: 10.2337/dc09-0723

20. Tricò D, Filice E, Baldi S, Frascerra S, Mari A, Natali A. Sustained effects of a protein and lipid preload on glucose tolerance in type 2 diabetes patients. Diabetes Metab. (2016) 42:242-8. doi: 10.1016/j.diabet.2016.03.004

21. Bonuccelli S, Muscelli E, Gastaldelli A, Barsotti E, Astiarraga BD, Holst JJ, et al. Improved tolerance to sequential glucose loading (Staub-Traugott effect): size and mechanisms. Am J Physiol Endocrinol Metab. (2009) 297:E532-E7. doi: 10.1152/ajpendo.00127.2009

22. Frape DL, Williams NR, Scriven A, Palmer CR, O'Sullivan K, Fletcher RJ. Diurnal trends in responses of blood plasma concentrations of glucose, insulin, and C-peptide following high-and low-fat meals and their relation to fat metabolism in healthy middle-aged volunteers. Br J Nutr. (1997) 77:523-35. doi: 10.1079/BJN19970054

23. Chen MJ, Jovanovic A, Taylor R. Utilizing the second-meal effect in type 2 diabetes: practical use of a soya-yogurt snack. Diabetes Care. (2010) 33:2552-4. doi: 10.2337/dc10-0552

24. Frid AH, Nilsson M, Holst JJ, Björck IME. Effect of whey on blood glucose and insulin responses to composite breakfast and lunch meals in type 2 diabetic subjects. Am J Clin Nutr. (2005) 82:69-75. doi: 10.1093/ajcn/ 82.1 .69

25. Salehi A, Gunnerud U, Muhammed SJ, Östman E, Holst JJ, Björck I, et al. The insulinogenic effect of whey protein is partially mediated by a direct effect of amino acids and GIP on $\beta$-cells. Nutr Metab. (2012) 9:48. doi: 10.1186/1743-7075-9-48

26. Lindgren O, Pacini G, Tura A, Holst JJ, Deacon CF, Ahrén B. Incretin effect after oral amino acid ingestion in humans. J Clin Endocrinol Metab. (2015) 100:1172-6. doi: 10.1210/jc.2014-3865

27. Nilsson M, Holst JJ, Björck IM. Metabolic effects of amino acid mixtures and whey protein in healthy subjects: studies using glucose-equivalent drinks. Am J Clin Nutr. (2007) 85:996-1004. doi: 10.1093/ajcn/85.4.996

28. Nongonierma AB, FitzGerald RJ. Dipeptidyl peptidase IV inhibitory and antioxidative properties of milk protein-derived dipeptides and hydrolysates. Peptides. (2013) 39:157-63. doi: 10.1016/j.peptides.2012.11.016

29. Tulipano G, Faggi L, Nardone A, Cocchi D, Caroli AM. Characterisation of the potential of $\beta$-lactoglobulin and $\alpha$-lactalbumin as sources of bioactive peptides affecting incretin function: in silico and in vitro comparative studies. Int Dairy J. (2015) 48:66-72. doi: 10.1016/j.idairyj.2015.01.008

30. Gunnarsson PT, Winzell MSr, Deacon CF, Larsen MO, Jelic K, Carr RD, et al. Glucose-induced incretin hormone release and inactivation are differently modulated by oral fat and protein in mice. Endocrinology. (2006) 147:317380. doi: 10.1210/en.2005-1442

31. Jakubowicz D, Froy O, Ahren B, Boaz M, Landau Z, Bar-Dayan Y, et al. Incretin, insulinotropic and glucose-lowering effects of whey protein preload in type 2 diabetes: a randomised clinical trial. Diabetologia. (2014) 57:1807-11. doi: 10.1007/s00125-014-3305-x

32. Watson LE, Phillips LK, Wu T, Bound MJ, Checklin H, Grivell J, et al. Differentiating the effects of whey protein and guar gum preloads on postprandial glycemia in type 2 diabetes. Clin Nutr. (2019) 38:282732. doi: 10.1016/j.clnu.2018.12.014

33. Wu T, Little TJ, Bound MJ, Borg M, Zhang X, Deacon CF, et al. A protein preload enhances the glucose-lowering efficacy of vildagliptin in type 2 diabetes. Diabetes Care. (2016) 39:511-7. doi: 10.2337/dc15-2298
34. Ma J, Jesudason DR, Stevens JE, Keogh JB, Jones KL, Clifton PM, et al. Sustained effects of a protein 'preload'on glycaemia and gastric emptying over 4 weeks in patients with type 2 diabetes: a randomized clinical trial. Diabetes Res Clin Pract. (2015) 108:e31-4. doi: 10.1016/j.diabres.2015. 02.019

35. Deane AM, Nguyen NQ, Stevens JE, Fraser RJL, Holloway RH, Besanko LK, et al. Endogenous glucagon-like peptide-1 slows gastric emptying in healthy subjects, attenuating postprandial glycemia. J Clin Endocrinol Metab. (2010) 95:215-21. doi: 10.1210/jc.2009-1503

36. Schirra J, Nicolaus M, Roggel R, Katschinski M, Storr M, Woerle HJ, et al. Endogenous glucagon-like peptide 1 controls endocrine pancreatic secretion and antro-pyloro-duodenal motility in humans. Gut. (2006) 55:243-51. doi: 10.1136/gut.2004.059741

37. Horowitz M, Edelbroek MAL, Wishart JM, Straathof JW. Relationship between oral glucose tolerance and gastric emptying in normal healthy subjects. Diabetologia. (1993) 36:857-62. doi: 10.1007/BF00400362

38. Watson LE, Xie C, Wang X, Li Z, Phillips LK, Sun Z, et al. Gastric emptying in patients with well-controlled type 2 diabetes compared with young and older control subjects without diabetes. J Clin Endocrinol Metab. (2019) 104:3311-9. doi: 10.1210/jc.2018-02736

39. Boronikolos GC, Menge BA, Schenker N, Breuer TG, Otte J-M, Heckermann $\mathrm{S}$, et al. Upper gastrointestinal motility and symptoms in individuals with diabetes, prediabetes and normal glucose tolerance. Diabetologia. (2015) 58:1175-82. doi: 10.1007/s00125-015-3538-3

40. Juel CT, Lund A, Andersen MM, Hansen CP, Storkholm JH, Rehfeld JF, et al. The GLP-1 receptor agonist lixisenatide reduces postprandial glucose in patients with diabetes secondary to total pancreatectomy: a randomised, placebo-controlled, double-blinded crossover trial. Diabetologia. (2020) 63:1285-98. doi: 10.1007/s00125-020-05158-9

41. Little TJ, Pilichiewicz AN, Russo A, Phillips L, Jones KL, Nauck MA, et al. Effects of intravenous glucagon-like peptide-1 on gastric emptying and intragastric distribution in healthy subjects: relationships with postprandial glycemic and insulinemic responses. J Clin Endocrinol Metab. (2006) 91:1916-23. doi: 10.1210/jc.2005-2220

42. King DG, Walker M, Campbell MD, Breen L, Stevenson EJ, West DJ. A small dose of whey protein co-ingested with mixed-macronutrient breakfast and lunch meals improves postprandial glycemia and suppresses appetite in men with type 2 diabetes: a randomized controlled trial. Am J Clin Nutr. (2018) 107:550-7. doi: 10.1093/ajcn/nqy019

43. Mortensen LS, Holmer-Jensen J, Hartvigsen ML, Jensen VK, Astrup A, de Vrese $M$, et al. Effects of different fractions of whey protein on postprandial lipid and hormone responses in type 2 diabetes. Eur J Clin Nutr. (2012) 66:799-805. doi: 10.1038/ejcn.2012.48

44. Akhavan T, Luhovyy BL, Brown PH, Cho CE, Anderson GH. Effect of premeal consumption of whey protein and its hydrolysate on food intake and postmeal glycemia and insulin responses in young adults. Am J Clin Nutr. (2010) 91:966-75. doi: 10.3945/ajcn.2009.28406

45. Akhavan T, Luhovyy BL, Panahi S, Kubant R, Brown PH, Anderson GH. Mechanism of action of pre-meal consumption of whey protein on glycemic control in young adults. J Nutr Biochem. (2014) 25:3643. doi: 10.1016/j.jnutbio.2013.08.012

46. Allerton DM, Rumbold PL, West DJ, Stevenson EJ. Effect of supplemental whey protein timing on postprandial glycaemia in centrally obese males. Br J Nutr. (2019) 121:637-46. doi: 10.1017/S00071145180 03793

47. Bjørnshave A, Hermansen K, Holst JJ. Pre-meal effect of whey proteins on metabolic parameters in subjects with and without type 2 diabetes: a randomized, crossover trial. Nutrients. (2018) 10:122. doi: 10.3390/nu10020122

48. Mortensen LS, Hartvigsen ML, Brader LJ, Astrup A, Schrezenmeir J, Holst JJ, et al. Differential effects of protein quality on postprandial lipemia in response to a fat-rich meal in type 2 diabetes: comparison of whey, casein, gluten, and cod protein. Am J Clin Nutr. (2009) 90:418. doi: 10.3945/ajcn.2008.27281

49. Davies MJ, Gagliardino JJ, Gray LJ, Khunti K, Mohan V, Hughes R. Realworld factors affecting adherence to insulin therapy in patients with Type 1 or Type 2 diabetes mellitus: a systematic review. Diabet Med. (2013) 30:512-24. doi: 10.1111/dme.12128 
50. Polonsky WH, Henry RR. Poor medication adherence in type 2 diabetes: recognizing the scope of the problem and its key contributors. Patient Prefer Adherence. (2016) 10:1299-307. doi: 10.2147/PPA.S106821

51. Bjørnshave A, Johansen TN, Amer B, Dalsgaard TK, Holst JJ, Hermansen K. Pre-meal and postprandial lipaemia in subjects with the metabolic syndrome: effects of timing and protein quality (randomised crossover trial). Br J Nutr. (2019) 121:312-21. doi: 10.1017/S0007114518003264

52. Watson LE, Phillips LK, Wu T, Bound MJ, Checklin HL, Grivell J, et al. A whey/guar "preload" improves postprandial glycaemia and glycated haemoglobin levels in type 2 diabetes: a 12-week, single-blind, randomized, placebo-controlled trial. Diabetes Obes Metab. (2019) 21:9308. doi: 10.1111/dom.13604

53. Hutchison AT, Piscitelli D, Horowitz M, Jones KL, Clifton PM, Standfield S, et al. Acute load-dependent effects of oral whey protein on gastric emptying, gut hormone release, glycemia, appetite, and energy intake in healthy men. Am J Clin Nutr. (2015) 102:1574-84. doi: 10.3945/ajcn.115.117556

54. Pal S, Ellis V, Dhaliwal S. Effects of whey protein isolate on body composition, lipids, insulin and glucose in overweight and obese individuals. Br J Nutr. (2010) 104:716-23. doi: 10.1017/S0007114510000991

55. Lindgren O, Mari A, Deacon CF, Carr RD, Winzell MS, Vikman J, et al. Differential islet and incretin hormone responses in morning versus afternoon after standardized meal in healthy men. J Clin Endocrinol Metab. (2009) 94:2887-92. doi: 10.1210/jc.2009-0366

56. Jakubowicz D, Wainstein J, Ahren B, Bar-Dayan Y, Landau Z, Rabinovitz $\mathrm{HR}$, et al. High-energy breakfast with low-energy dinner decreases overall daily hyperglycaemia in type 2 diabetic patients: a randomised clinical trial. Diabetologia. (2015) 58:912-9. doi: 10.1007/s00125-015-3524-9

57. Saad A, Dalla Man C, Nandy DK, Levine JA, Bharucha AE, Rizza RA, et al. Diurnal pattern to insulin secretion and insulin action in healthy individuals. Diabetes. (2012) 61:2691-700. doi: 10.2337/db11-1478

58. DeFronzo RA, Stonehouse AH, Han J, Wintle ME. Relationship of baseline HbAlc and efficacy of current glucose-lowering therapies: a meta-analysis of randomized clinical trials. Diabet Med. (2010) 27:30917. doi: 10.1111/j.1464-5491.2010.02941.x

59. Nauck MA, Kemmeries G, Holst JJ, Meier JJ. Rapid tachyphylaxis of the glucagon-like peptide 1-induced deceleration of gastric emptying in humans. Diabetes. (2011) 60:1561-5. doi: 10.2337/db10-0474

60. Umapathysivam MM, Lee MY, Jones KL, Annink CE, Cousins CE, Trahair LG, et al. Comparative effects of prolonged and intermittent stimulation of the glucagon-like peptide 1 receptor on gastric emptying and glycemia. Diabetes. (2014) 63:785-90. doi: 10.2337/db13-0893

61. Cunningham KM, Daly J, Horowitz M, Read NW. Gastrointestinal adaptation to diets of differing fat composition in human volunteers. Gut. (1991) 32:483-6. doi: 10.1136/gut.32.5.483

62. Horowitz M, Cunningham KM, Wishart JM, Jones KL, Read NW. The effect of short-term dietary supplementation with glucose on gastric emptying of glucose and fructose and oral glucose tolerance in normal subjects. Diabetologia. (1996) 39:481-6. doi: 10.1007/BF00400681

63. Gale EA, Beattie SD, Hu J, Koivisto V, Tan MH. Recruitment to a clinical trial improves glycemic control in patients with diabetes. Diabetes Care. (2007) 30:2989-92. doi: 10.2337/dc07-0155

64. Avery L, Flynn D, van Wersch A, Sniehotta FF, Trenell MI. Changing physical activity behavior in type 2 diabetes: a systematic review and meta-analysis of behavioral interventions. Diabetes Care. (2012) 35:26819. doi: $10.2337 / \mathrm{dc} 11-2452$

65. Brinkworth GD, Noakes M, Keogh JB, Luscombe ND, Wittert GA, Clifton PM. Long-term effects of a high-protein, low-carbohydrate diet on weight control and cardiovascular risk markers in obese hyperinsulinemic subjects. Int J Obes Relat Metab Disord. (2004) 28:661-70. doi: 10.1038/sj.ijo. 0802617

66. Beck RW, Connor CG, Mullen DM, Wesley DM, Bergenstal RM. The fallacy of average: how using HbAlc alone to assess glycemic control can be misleading. Diabetes Care. (2017) 40:994-9. doi: 10.2337/dc17-0636

67. Battelino T, Danne T, Bergenstal RM, Amiel SA, Beck R, Biester $\mathrm{T}$, et al. Clinical targets for continuous glucose monitoring data interpretation: recommendations from the international consensus on time in range. Diabetes Care. (2019) 42:1593-603. doi: 10.2337/dci190028
68. Almario RU, Buchan WM, Rocke DM, Karakas SE. Glucose-lowering effect of whey protein depends upon clinical characteristics of patients with type 2 diabetes. BMJ Open Diabetes Res Care. (2017) 5:e000420. doi: 10.1136/bmjdrc-2017-000420

69. Edelman SV, Polonsky WH. Type 2 diabetes in the real world: the elusive nature of glycemic control. Diabetes Care. (2017) 40:142532. doi: $10.2337 / \mathrm{dc} 16-1974$

70. Ringborg A, Lindgren P, Yin D, Martinell M, Stålhammar J. Time to insulin treatment and factors associated with insulin prescription in Swedish patients with type 2 diabetes. Diabetes Metab. (2010) 36:198203. doi: 10.1016/j.diabet.2009.11.006

71. Hare KJ, Vilsbøll T, Asmar M, Deacon CF, Knop FK, Holst JJ. The glucagonostatic and insulinotropic effects of glucagon-like peptide-1 contribute equally to its glucose-lowering action. Diabetes. (2010) 59:176570. doi: $10.2337 / \mathrm{db} 09-1414$

72. Ayala JE, Bracy DP, James FD, Julien BM, Wasserman DH, Drucker DJ. The glucagon-like peptide-1 receptor regulates endogenous glucose production and muscle glucose uptake independent of its incretin action. Endocrinology. (2008) 150:1155-64. doi: 10.1210/en.2008-0945

73. Kielgast U, Holst JJ, Madsbad S. Antidiabetic actions of endogenous and exogenous GLP-1 in type 1 diabetic patients with and without residual $\beta$-cell function. Diabetes. (2011) 60:1599-607. doi: 10.2337/db10-1790

74. Hope SV, Knight BA, Shields BM, Hill AV, Choudhary P, Strain WD, et al. Random non-fasting C-peptide testing can identify patients with insulintreated type 2 diabetes at high risk of hypoglycaemia. Diabetologia. (2018) 61:66-74. doi: 10.1007/s00125-017-4449-2

75. Drucker DJ, Nauck MA. The incretin system: glucagon-like peptide-1 receptor agonists and dipeptidyl peptidase- 4 inhibitors in type 2 diabetes. Lancet. (2006) 368:1696-705. doi: 10.1016/S0140-6736(06)69705-5

76. Arnolds S, Dellweg S, Clair J, Dain MP, Nauck MA, Rave K, et al. Further improvement in postprandial glucose control with addition of exenatide or sitagliptin to combination therapy with insulin glargine and metformin: a proof-of-concept study. Diabetes Care. (2010) 33:150915. doi: 10.2337/dc09-2191

77. Buse JB, Bergenstal RM, Glass LC, Heilmann CR, Lewis MS, Kwan AY, et al. Use of twice-daily exenatide in basal insulin-treated patients with type 2 diabetes: a randomized, controlled trial. Ann Intern Med. (2011) 154:103-12. doi: 10.7326/0003-4819-154-2-201101180-00300

78. Allerton DM, West DJ, Stevenson EJ. Whey protein consumption following fasted exercise reduces early postprandial glycaemia in centrally obese males: a randomised controlled trial. Eur J Nutr. doi: 10.1007/s00394-020-02304-2. [Epub ahead of print].

79. MacDonald A, Lilburn MM, Davies P, Evans S, Daly A, Hall S, et al. 'Ready to drink'protein substitute is easier is for people with phenylketonuria. J Inherit Metab Dis. (2006) 29:526-31. doi: 10.1007/s10545-006-0234-y

80. Glanz K, Basil M, Maibach E, Goldberg J, Snyder D. Why Americans eat what they do: taste, nutrition, cost, convenience, and weight control concerns as influences on food consumption. J Am Diet Assoc. (1998) 98:1118-26. doi: 10.1016/S0002-8223(98)00260-0

81. Linn T, Strate C, Schneider K. Diet promotes beta-cell loss by apoptosis in prediabetic nonobese diabetic mice. Endocrinology. (1999) 140:376773. doi: 10.1210 /endo. 140.8 .6940

82. Schneider K, Laube H, Linn T. A diet enriched in protein accelerates diabetes manifestation in NOD mice. Acta Diabetol. (1996) 33:23640. doi: 10.1007/BF02048550

83. U.K. Prospective Diabetes Study Group. U.K. prospective diabetes study 16. Overview of 6 years' therapy of type II diabetes: a progressive disease. Diabetes. (1995) 44:1249-58. doi: 10.2337/diab.44.11.1249

84. Gentile S, Strollo F, Viazzi F, Russo G, Piscitelli P, Ceriello A, et al. Five-year predictors of insulin initiation in people with type 2 diabetes under real-life conditions. J Diabetes Res. (2018) 2018:7153087. doi: 10.1155/2018/7153087

85. Del Prato S, Leonetti F, Simonson D, Sheehan P, Matsuda M, DeFronzo RA. Effect of sustained physiologic hyperinsulinaemia and hyperglycaemia on insulin secretion and insulin sensitivity in man. Diabetologia. (1994) 37:1025-35. doi: 10.1007/BF00400466

86. Reaven GM. Insulin resistance and compensatory hyperinsulinemia: role in hypertension, dyslipidemia, and coronary heart disease. Am Heart J. (1991) 121(4 Pt 2):1283-8. doi: 10.1016/0002-8703(91)90434-J 
87. Bjørnshave A, Holst JJ, Hermansen K. A pre-meal of whey proteins induces differential effects on glucose and lipid metabolism in subjects with the metabolic syndrome: a randomised cross-over trial. Eur J Nutr. (2018) 58:755-64. doi: 10.1007/s00394-018-1684-3

88. Baer DJ, Stote KS, Paul DR, Harris GK, Rumpler WV, Clevidence BA. Whey protein but not soy protein supplementation alters body weight and composition in free-living overweight and obese adults. J Nutr. (2011) 141:1489-94. doi: 10.3945/jn.111.139840

89. Pal S, Ellis V. The chronic effects of whey proteins on blood pressure, vascular function, and inflammatory markers in overweight individuals. Obesity (Silver Spring). (2010) 18:1354-9. doi: 10.1038/oby.2009.397

90. Shimomura I, Matsuda M, Hammer RE, Bashmakov Y, Brown MS, Goldstein JL. Decreased IRS-2 and increased SREBP-1c lead to mixed insulin resistance and sensitivity in livers of lipodystrophic and ob/ob mice. Mol Cell. (2000) 6:77-86. doi: 10.1016/S1097-2765(05)00010-9

91. Utzschneider KM, Kahn SE. Review: the role of insulin resistance in nonalcoholic fatty liver disease. J Clin Endocrinol Metab. (2006) 91:475361. doi: $10.1210 /$ jc.2006-0587

92. Adiels M, Taskinen MR, Packard C, Caslake MJ, Soro-Paavonen A, Westerbacka J, et al. Overproduction of large VLDL particles is driven by increased liver fat content in man. Diabetologia. (2006) 49:75565. doi: 10.1007/s00125-005-0125-Z

93. Nordestgaard BG, Benn M, Schnohr P, Tybjærg-Hansen A. Nonfasting triglycerides and risk of myocardial infarction, ischemic heart disease, and death in men and women. JAMA. (2007) 298:299-308. doi: 10.1001/jama.298.3.299

94. Wurtz P, Soininen P, Kangas AJ, Ronnemaa T, Lehtimaki T, Kahonen $\mathrm{M}$, et al. Branched-chain and aromatic amino acids are predictors of insulin resistance in young adults. Diabetes Care. (2013) 36:64855. doi: $10.2337 / \mathrm{dc} 12-0895$

95. Xu F, Tavintharan S, Sum CF, Woon K, Lim SC, Ong CN. Metabolic signature shift in type 2 diabetes mellitus revealed by mass spectrometry-based metabolomics. J Clin Endocrinol Metab. (2013) 98:E1060-5. doi: 10.1210/jc.2012-4132

96. Newgard CB, An J, Bain JR, Muehlbauer MJ, Stevens RD, Lien LF, et al. A branched-chain amino acid-related metabolic signature that differentiates obese and lean humans and contributes to insulin resistance. Cell Metab. (2009) 9:311-26. doi: 10.1016/j.cmet.2009.02.002

97. Lee CC, Watkins SM, Lorenzo C, Wagenknecht LE, Il'yasova D, Chen YD, et al. Branched-chain amino acids and insulin metabolism: the insulin resistance atherosclerosis study (IRAS). Diabetes Care. (2016) 39:5828. doi: $10.2337 / \mathrm{dc} 15-2284$

98. Wang TJ, Larson MG, Vasan RS, Cheng S, Rhee EP, McCabe E, et al. Metabolite profiles and the risk of developing diabetes. Nat Med. (2011) 17:448-53. doi: 10.1038/nm.2307

99. Smith GI, Yoshino J, Stromsdorfer KL, Klein SJ, Magkos F, Reeds $\mathrm{DN}$, et al. Protein ingestion induces muscle insulin resistance independent of leucine-mediated mTOR activation. Diabetes. (2015) 64:1555-63. doi: 10.2337/db14-1279

100. Tremblay F, Krebs M, Dombrowski L, Brehm A, Bernroider E, Roth E, et al. Overactivation of S6 kinase 1 as a cause of human insulin resistance during increased amino acid availability. Diabetes. (2005) 54:267484. doi: 10.2337/diabetes.54.9.2674

101. Krebs M, Krssak M, Bernroider E, Anderwald C, Brehm A, Meyerspeer M, et al. Mechanism of amino acid-induced skeletal muscle insulin resistance in humans. Diabetes. (2002) 51:599-605. doi: 10.2337/diabetes.51.3.599
102. She P, Van Horn C, Reid T, Hutson SM, Cooney RN, Lynch CJ. Obesity-related elevations in plasma leucine are associated with alterations in enzymes involved in branched-chain amino acid metabolism. Am J Physiol Endocrinol Metab. (2007) 293:E1552-63. doi: 10.1152/ajpendo.0013 4.2007

103. Haufe S, Engeli S, Kaminski J, Witt H, Rein D, Kamlage B, et al. Branched-chain amino acid catabolism rather than amino acids plasma concentrations is associated with diet-induced changes in insulin resistance in overweight to obese individuals. Nutr Metab Cardiovasc Dis. (2017) 27:858-64. doi: 10.1016/j.numecd.2017. 07.001

104. Shah SH, Crosslin DR, Haynes CS, Nelson S, Turer CB, Stevens RD, et al. Branched-chain amino acid levels are associated with improvement in insulin resistance with weight loss. Diabetologia. (2012) 55:32130. doi: 10.1007/s00125-011-2356-5

105. Pekmez CT, Bjornshave A, Pratico G, Hermansen K, Dragsted LO. Pre-meal protein intake alters postprandial plasma metabolome in subjects with metabolic syndrome. Eur J Nutr. (2019) 59:1881-94. doi: 10.1007/s00394-019-02039-9

106. Tricò D, Frascerra S, Baldi S, Mengozzi A, Nesti L, Mari A, et al. The insulinotropic effect of a high-protein nutrient preload is mediated by the increase of plasma amino acids in type 2 diabetes. Eur J Nutr. (2018) 58:2253-61. doi: 10.1007/s00394-018-1778-y

107. Hoefle AS, Bangert AM, Stamfort A, Gedrich K, Rist MJ, Lee YM, et al. Metabolic responses of healthy or prediabetic adults to bovine whey protein and sodium caseinate do not differ. J Nutr. (2015) 145:46775. doi: 10.3945/jn.114.199190

108. Calbet JA, MacLean DA. Plasma glucagon and insulin responses depend on the rate of appearance of amino acids after ingestion of different protein solutions in humans. J Nutr. (2002) 132:2174-82. doi: 10.1093/jn/ 132.8.2174

109. Holmer-Jensen J, Mortensen LS, Astrup A, de Vrese M, Holst JJ, Thomsen C, et al. Acute differential effects of dietary protein quality on postprandial lipemia in obese non-diabetic subjects. Nutr Res. (2013) 33:3440. doi: 10.1016/j.nutres.2012.11.004

110. Seghieri M, Rebelos E, Gastaldelli A, Astiarraga B, Casolaro A, Barsotti E, et al. Direct effect of GLP-1 infusion on endogenous glucose production in humans. Diabetologia. (2013) 56:156-61. doi: 10.1007/s00125-0122738-3

Conflict of Interest: DW and ES have received research funding from Arla Foods Ingredients (AFI), Viby J, Denmark. DW and ES have received travel expenses and consultancy fees from AFI. ES has received research funding from The Dairy Council. This review was written independently from industrial funders.

The remaining authors declare that the research was conducted in the absence of any commercial or financial relationships that could be construed as a potential conflict of interest.

Copyright (c) 2020 Smith, Bowden Davies, Stevenson and West. This is an open-access article distributed under the terms of the Creative Commons Attribution License (CC $B Y)$. The use, distribution or reproduction in other forums is permitted, provided the original author(s) and the copyright owner(s) are credited and that the original publication in this journal is cited, in accordance with accepted academic practice. No use, distribution or reproduction is permitted which does not comply with these terms. 